DOI: $10.35355 / 0000040$

\title{
NOTAS SOBRE A AMAZÔNIA E A POLÍTICA NO PENSAMENTO DE ÁLVARO MAIA
}

\author{
Paula Mirana de Sousa Ramos* \\ Universidade Federal do Amazonas- UFAM \\ pmsr20@yahoo.com.br
}

\begin{abstract}
RESUMO: Álvaro Maia destacou-se por sua atuação como político profissional ao longo de quatro décadas e revelou um projeto intelectual que além de forjar a nação, buscava compreender seu processo de modernização. A produção da obra literária de Maia não pode ser reduzida a uma mera estratégia para adquirir capital simbólico perdido no campo político. Como representante do movimento da Caboclitude, buscava através de suas obras construir uma identidade verdadeiramente cabocla. Neste trabalho apresentamos a análise das obras publicadas por Álvaro Maia após a década de 1930, onde é possível compreender de que forma seu pensamento político contribuiu para sua legitimação e permanência no campo político. Neste sentido, ao se inventariar a contribuição deste autor para o Pensamento Social da Amazônia e do Brasil, recuperamos uma interpretação histórica, social e ecológica da região, a qual revela a Amazônia em suas bases culturais, econômicas, sociais e políticas.
\end{abstract}

PALAVRAS-CHAVES: Amazônia- cabocla- campo político.

\section{NOTES ABOUT AMAZON AND POLITICS IN ÁLVARO MAIA'S THINKING}

\begin{abstract}
Maia stood out for his role as a professional politician for four decades and revealed an intellectual project that, besides forging the nation, sought to understand its modernization process. The production of Maia's literary work cannot be reduced to a mere strategy to acquire symbolic capital lost in the political field. As a representative of the Caboclitude movement, he sought through his works to build a truly cabocla identity. In this paper, we present the analysis of the works published by Álvaro Maia after the 1930s. It is possible to understand how his political thinking contributed to its legitimacy and permanence in the political field. In this sense, by inventing the contribution of this author to the Social Thought of the Amazon and Brazil, we recover a historical, social and ecological interpretation of the region, which reveals the Amazon in its cultural, economic, social and political bases.
\end{abstract}

KEYWORDS: Amazon- cabocla- political field.

* Doutora em Sociedade e Cultura na Amazônia pela Universidade Federal do Amazonas, atualmente professora do Departamento de Ciências Sociais da Universidade Federal do Amazonas. 


\section{INTRODUÇÃO}

Estudar a gênese do Pensamento Social brasileiro e Amazônico, por meio de uma análise da sociologia das obras, de intelectuais da primeira metade do século XX, como Álvaro Maia, nos auxilia no processo de esclarecimento do próprio pensamento social atual. Jornalista, escritor, advogado e político, tornou-se ainda nas primeiras décadas do século XX uma liderança intelectual e política, por encarnar os ideias e anseios de mudança esperados por diversos setores sociais diante de um cenário de crise no Amazonas.

As descrições sobre a realidade econômica, social e política da região estão presentes em toda sua obra literária e embora escritas em momentos diferentes de sua trajetória, referem-se ao auge e declínio do ciclo da borracha. Neste sentido, apesar desta contextualização histórica da sua obra literária, ela não se difere muito em conteúdo; por este motivo, no presente estudo não vamos obedecer a ordem cronológica das publicações, mas uma ordem lógica, com o objetivo de compreender melhor a abordagem dos temas e de que forma reverberavam em seu pensamento e ação política.

O primeiro tópico faz um itinerário sobre os temas amazônicos na produção literária de Álvaro Maia, seus livros publicados a partir da década de 1940, revelam um político e escritor consolidado. A heroificação do seringueiro foi uma das principais ideias defendidas por Maia em sua obra literária e em seu projeto político, onde tratavao como o agente mais apto a desenvolver a Amazônia e desta forma procurava descontruir as ideias preconceituosas que tratavam a região apenas como um lugar inóspito, selvagem e exótico. O processo civilizatório também faz parte da obra alvarena, onde o choque e o estranhamento estavam presentes na relação entre o patrão e a empregada indígena, do mesmo modo que o escritor revela o processo civilizatório presente nas relações entre seringalistas e seringueiros sendo que o uso de violência por parte dos seringalistas aos seringueiros brabos trata-se de uma forma de docilizar os esses corpos.

No segundo tópico buscou-se identificar como a militância política incidiu sobre a obra deste autor amazonense. A militância política refletiu no projeto literário de construção da identidade cabocla, uma complementação no plano prático. Neste sentido, é possível observa uma ambiguidade no seu posicionamento crítico, em especial ao tratamento dado ao seringalista, enfatizando que as condições precárias com as quais 
viviam o seringueiro, estavam associadas principalmente ao descaso do governo central com a região. Desta forma, seu tom crítico buscava tecer uma relação conciliatória com os setores locais dominantes. Sua crítica social nos ajuda a compreender o posicionamento dos intelectuais marginais com relação ao nacionalismo estatal e populista, desvelando que a ordem social no interior da Amazônia é cercada de uma relação complexa e ambígua com a moderna sociedade capitalista, no qual o homem do interior estabelecia suas relações de trabalho e de cidadania dentro das práticas de proteção e clientelismos presentes no econômica gomífera.

\section{TEMAS AMAZÔNICOS NA LITERATURA ALVAREANA}

Ao focar importância para o posicionamento social e político desses intelectuais amazonenses da primeira metade do século XX, é mister compreender os matizes ideológicos e sociológicos que nortearam as obras e seus posicionamentos, onde não só os autores, mas suas ideias são importantes para uma compreensão do Pensamento Social Amazônico e do Brasil.

A necessidade de se estudar a gênese do pensamento social da região, por meio de uma releitura das obras de autores como/Álvaro Maia, se dá no sentido de obter um esclarecimento do próprio pensamento social atual. Torna-se importante, portanto, resgatar as discussões em torno da compreensão dos processos e das estruturas que articularam a região amazônica com o restante do Brasil e com o mundo. Segundo Bastos \& Freitas Pinto (2014, p.25) para tal propósito era necessário apreender o Pensamento Social em suas diferentes formas, tanto as sistematizadas pelas Ciências Sociais como nas inquietações intelectuais de homens públicos, ensaístas, cronistas, políticos, entre outros.

Neste sentido, a Amazônia é representada na obra alvareana a partir do tratamento dado ao sistema de extração da borracha. No livro Beiradão (1999), o seringueiro é tratado como o verdadeiro desbravador, o agente responsável pelo projeto de "conquistar" a região, adentrando os bamburrais e os beiradões, onde se estabeleciam, construindo seus barracões e fazendo plantações a fim de se estabelecerem com suas famílias. Segundo Álvaro Maia estas eram as verdadeiras inciativas civilizatórias na região amazônica. No livro Na Vanguarda da Retaguarda (MAIA, 1943), seu primeiro livro publicado, o seringueiro surge como a vanguarda 
desbravadora, e apesar do despontar do processo de industrialização da Amazônia, não perdeu seu papel de destaque.

O sistema de extração da borracha serviu de tema para inúmeras ficções e estudos sociológicos. Este tema torna-se uma referência para a formação do movimento de valorização do elemento nativo na literatura e no pensamento social amazônico. Temas como o mundo do seringal, o sistema de aviação, a relação entre o seringueiro e o patrão eram fortemente enfatizados nestas obras e foi amplamente explorado no final do século XIX, passando por décadas do século XX.

O enfoque destas obras tem uma particularidade: ou tratava o sistema de um ponto de vista macro, ou sob a relação entre o seringalista e o seringueiro. Segundo Lima (2009. p.241), o enfoque dado ao tema acentua mais um ambiente do que outro. A abordagem literária do ciclo da borracha ressalta a ideia do infernismo do processo extrativo, reforçando a exploração da região e do homem amazônico em torno da relação de trabalho entre seringalistas e seringueiros. Como Álvaro Maia afirma no trecho do livro Beiradão: “[...] o proprietário não pagava os saldos, furava as meninas impúberes, enfeitava os seringueiros, principalmente com dívidas, eram os juros de mora" (MAIA, 1999, p.120). O tratamento dado ao seringueiro gira em torno da submissão e subserviência em relação ao patrão e a barbárie daqueles homens, que sem valoração alguma sucumbem a sedução da possibilidade de riqueza através do hévea. Ainda no mesmo trecho do livro afirma que: "o cangaço daqui é revolta e tragédia" (MAIA, 1999, p.121), referindo-se a ideia de que nesta região as relações entre os patrões e os empregados são pautadas por leis próprias, que às vezes beiravam a selvageria.

Os brabos como são denominados os seringueiros novatos e os mansos os seringueiros experientes, reforçavam a construção dos estereótipos que brutalizam esses indivíduos. Álvaro Maia, além do tom realístico que muito se assemelha às abordagens anteriores sobre o seringueiro, traz como novidade a esse tratamento o argumento de ser apenas o narrador das experiências vividas por eles, ao afirmar que os seringueiros que ele trata em sua obra fazem parte das histórias recolhidas ao longo de trajetória, sendo ele mesmo um filho do Madeira (referência a sua região de origem em Humaitá).

Álvaro Maia revela uma intencionalidade ao assumir o papel de narrador das histórias publicadas nesses livros e se coloca na condição de porta-voz das camadas mais populares, eximindo-se assim de inúmeras acusações que vinha sofrendo sobre sua 
atividade política. Afirmava no livro Nas Barras do Pretório (MAIA, 1958, p.14): "Quando tomba um governante, vencido por adversários nos embates eleitorais, iniciam-se a execração e a cremação. [...] Imagina-se a situação de um ex-governante sem trincheiras defensivas". Quando se coloca na condição de apenas um narrador e compilador das histórias, ele assume uma condição de proximidade com o seringueiro, neste sentido, se exime da acusação de ser apenas mais um dos intérpretes do infernismo, no qual tanto seringueiros como seringalistas fazem parte por serem os únicos degenerados ao ponto de se submeterem a essas condições inóspitas em busca de riquezas, movidos pela mais vil paixão mundana.

Essas relações de trabalho se estabelecem de modo distinto e complementares, diferente dos barões da borracha mais ligados às cidades de Belém e Manaus. Revivendo o luxo e ostentação das grandes metrópoles, os seringalistas abordados também fazem parte do cenário do seringal e criam junto com o seringueiro um modus vivendi. Todavia, essa relação era marcada por um regime que beirava a escravidão como ele retoma no livro Beiradão: "Os patrões conservavam rigoroso segredo sobre os preços, [...] Não explicavam o preço [...] dos gêneros principais que vinham de Manaus" (MAIA, 1999, p.104).

Álvaro Maia quando aborda as duas personagens neste romance e em outras obras, ressalta os aspectos da adaptabilidade deles ao meio. Em seus relatos aparecem de modo bem delimitado a referência aos grupos sociais envolvidos neste processo, bem como a ideia de que somente os mais fortes e mais aptos conseguiriam se adaptar às florestas, os igarapés, e os braços do rio Madeira.

Como pertencente ao movimento nativista não partiu da perspectiva de que somente os agentes mais aptos seriam apenas as pessoas vindas de fora, em semelhança a ideia raciológica de que as raças brancas desenvolvidas e civilizadas seriam as mais capazes de dar cabo ao projeto de desenvolvimento da região.

O seringueiro é abordado a partir de um enfoque de heroificação. Em sua poesia o seringueiro heroificado é comparado à mitologia grega através da figura de Hércules. No entanto, não devemos esquecer de que a valorização da figura do seringueiro sempre fez parte do seu programa político, portanto, apesar de enfatizar o processo de adaptabilidade entre os brabos e os mansos, ele ressaltava que esse processo não era apenas um condicionamento ambiental, mas uma ausência de investimentos e assistência política. Em sua trajetória inicial, o seringueiro hercúleo não tinha o 
principal motivo de luta as condições inóspitas, nem a falta de investimentos tecnológicos por parte dos comerciantes, mas ele atribui como principal causa para a desvalorização do seringueiro a falta de assistência política em que os seringueiros extraiam o látex.

No período da publicação do Beiradão (1999), Maia com uma carreira política já consolidada, estava passando por uma espécie de "exílio político" e já não podia atribuir a culpa dos problemas da região ao descaso os grupos políticos do passado. No entanto, apesar de atribuir para si uma mea culpa em relação ao seringueiro, ele aborda a vida no interior através de apadrinhamentos, manobras políticas, disputas e abusos de poder, isso reflete o tempo político em que publicou esse romance, período em que estava afastado das atividades políticas.

Diante de um contexto de instabilidade política, com o fim do Estado Novo e período de redemocratização, podemos observar em Álvaro Maia o processo de interdependência entre a arte/literatura e a política, pois conforme Chaia (2007. p. 34) são duas dimensões diferentes que se entrecruzam ao atingirem diferentes dimensões da vida humana. Isso se dá porque os sujeitos, perante os desafios presentes nas relações sociais, tais como as crescentes mudanças da modernidade, o fim da Segunda Guerra Mundial e a inserção do Brasil no capitalismo globalizado, procuram agir no intuito de intervir nos acontecimentos sociais através de respostas às questões com que se deparam. Para Maia, a produção intelectual e o engajamento político surgiram como formas de tentar compreender e transformar esta realidade.

De acordo com Goldemann (1967, p.254), o processo de adaptação da realidade a partir das conveniências sociais faz com que os indivíduos tornam seus comportamentos em espécies de estruturas significativas e coerentes. Essa estrutura ocorre a partir da interação do grupo social, procurando dar respostas às suas expectativas. Assim, a criação artística torna-se uma forma significativa e articulada de expressão das possibilidades objetivas que estão nesse grupo social. Podemos entender que Álvaro Maia elaborou suas visões de mundo como parte de suas experiências na vida política e na vida pessoal, que necessariamente essas mesmas visões eram compartilhadas com um ou mais grupos sociais. Isto significa que sua obra literária foi se construindo coletivamente. Os literatos são portanto, formuladores de ideias, vinculando visões de mundo que são construídas coletivamente, sendo esta a função de intelectuais dentro da sociedade. 
No entanto, ao analisar a trajetória de Álvaro Maia observamos que essa estrutura relaciona a sua obra literária com determinadas condições de produção, dadas pela estrutura de campo literário e pelo contexto social mais abrangente em um dado período histórico. Isto é, essas condições são determinantes para compreendermos por exemplo, mudanças inclusive nas visões de mundo deste autor, ora para reforçar um status quo, ora para se manifestar contrário a este. Em sua trajetória inicial, publicava seus poemas, crônicas e contos em jornais e em revistas, devido ao fato de que o mercado editorial ainda não ser totalmente autônomo, e as condições de vinculação e cooptação dos escritores ainda estarem ligadas à imprensa.

As estruturas sociais, literárias e políticas são constituídas por diversos atores, que de uma forma individual ou organizada coletivamente, produzem diferentes posições sociais e políticas que convergem e se opõe entre si. Assim, de acordo com Bourdieu (1996, p.329) a estrutura social, sua posição no campo literário e no campo político está intimamente ligada a sua trajetória: os grupos sociais com quem se articulava, o tipo de público de suas obras, o modo de recepção de seu textos, etc. No período da publicação de seus livros o mercado editorial já possuía uma consolidação diferente do que no período de sua trajetória inicial. Outro ponto importante é que durante a década de 1950, período em que ele mais publicou livros, foi também o período em que Maia sofria inúmeras oscilações políticas entre mandatos e perdas de mandatos. Somente na década de 1960 que retorna ao cenário político com um mandato biônico.

Segundo Paiva (2002, p.104) o movimento nativista regional se origina como uma resposta da elite oligárquica decadente, no sentido de criar uma estratégia para ainda participar do campo do poder, através da valorização do elemento nativo. Com isso, surge o movimento da Caboclitude, no qual Maia era um dos principais representantes. Deste modo, na construção do personagem de Fábio Moura no livro Beiradão (1999) em muito revela a angústia em construir um posicionamento que possa atingir a dimensão subjetiva das relações humanas e do poder e, ao mesmo tempo, manter uma ótica realista da própria estruturação e autonomia do campo cultural e político.

Em seu programa político no período do Estado Novo já tipificava o seringueiro como o soldado caboclo, no livro Na Vanguarda da Retaguarda (1943), usou o termo o novo seringueiro. Este novo seringueiro que é fruto dos primeiros 
desbravadores da região (primeiros seringueiros), assumirá seu papel cívico nas trincheiras da borracha, contribuindo para a segurança da Pátria e o desenvolvimento da região.

A presença nordestina é recorrente na obra de Álvaro Maia, como podemos observar em três personagens marcantes no livro Beiradão (1999): Firmo Segadais, Padre Silveira e Fabio Moura, sendo este último uma importante representação sobre o seringueiro e o seringalista, pelas suas características de humanidade e a forma como trata com os seringueiros. A construção dessas personagens busca descontruir a imagem estigmatizada ainda em Alberto Rangel sobre o homem dentro do espaço amazônico, como um produto social condicionado. Assim, com base nas circunstâncias, seja a busca aventureira por novas riquezas, seja a fuga de crises em sua terra de origem, este indivíduo foi obrigado a reaprender tudo, adaptando-se ou desaparecendo. Neste contexto, Monteiro (1976, p.330) afirma que a literatura amazonense criou uma espécie de mito em torno da participação do nordestino na ocupação da Amazônia. Houve certo exagero, pois apesar de sua inegável participação no processo de desbravamento do imenso vale verde, para essa região vieram brasileiros das mais diversas regiões do país, bem como bolivianos e imigrantes de outras partes do mundo.

Segundo Norbert Elias (1994, p.279) a ideia de civilização está relacionada a um longo processo de aprendizagem "involuntária”, no qual os indivíduos transformaram suas relações com os corpos, sentimentos e suas próprias estruturas sociais. Com o advento da modernidade, essa transformação dos comportamentos humanos seriam um processo destinado apenas às camadas mais altas da sociedade, tal processo era comum a todos os indivíduos, ideia que vai de encontro às intenções expansionistas desses grupos europeus em especial, os franceses e ingleses, com o seu estilo de vida de côrte que influenciaram os colonizadores das terras amazônicasportugueses e espanhóis.

Esse processo de transformação tomou um caráter universalista, portanto quando pensamos no seringueiro como um agente civilizador, partimos da ideia de universalizar esses costumes. No caso da relação abordada por Álvaro Maia entre o seringueiro e sua missão desbravadora e os índios, observamos como essas transformações ocorreram no cotidiano amazônico. A índia Narcisa retratada no Beiradão e em outras obras do autor revela esse processo de transformação no qual retirou-os da barbárie e da incivilização. 
Nessa ocasião, como presente e cumprimento de palavra entregou Narcisa. -O resto você sabe, Padre Silveira. Foi você que a batizou. Deixou uma filha que uniu as duas raças- o cearense e o índio, o sertão e a selva, o nordeste e o norte. Amamentou o menino mais velho, em seus seios selvagens, que traziam o sangue forte da solidão. Concentrava-se, numa gota de leite, o mistério amazônico. [...] Como não vigiar Narcisa, em sua paixão pelo curumim, que lhe retribuía o mesmo sentimento, ouvindo-lhe as histórias de lobisomem e índios em luta? Ensinavam-lhe, por outro lado, o Padre-Nosso, a Ave-Maria, e ele crescia entre as orações a Deus verdadeiro do Padre Silveira e ao Tupã de Narcisa (MAIA, 1999. pp. 206-207).

O estranhamento entre os comportamentos apresentados através da índia Narcisa revelam o próprio choque civilizatório. Tal estranhamento refere-se a um dos sentimentos dominantes do processo civilizador, ou seja, causa-nos mal-estar tudo que se refere ao "incivilizado" ou "bárbaro".

Ao analisar a personagem de Narcisa, observamos que a catequização foi o recurso utilizado para que seus comportamentos e emoções passassem de um estranhamento para os padrões considerados aceitáveis. No trecho do romance acima, nota-se um conflito entre a dedicação à crença ocidental (Cristianismo) e suas crenças tradicionais que ainda estavam impregnadas em suas práticas religiosas, ou seja, ora agindo como uma cristã civilizada, ora agindo como uma pagã selvagem.

No entanto, Maia também buscou em seu tratamento sobre os índios tentar despi-los desse estranhamento, na medida em que reduzia o exótico a uma perspectiva de índios que no final das contas conseguiam assimilar uma série de comportamentos "aceitáveis" universalmente, isto é, deixando de bárbaros e passando a conviver em ambiência civilizada.

Além das descrições sobre o processo civilizador indígena na região, a própria relação entre patrão e seringueiro perpassa por uma cadeia produtiva que descreve o processo modernizador na região amazônica. Tal processo, no plano simbólico, buscou desde sua concepção no Renascimento em um constante progresso às sociedades, que seria capaz de transformar a vida humana cada vez mais confortável e segura. No entanto, esse projeto modernizador sempre esteve cercado de ambiguidades. Pois em nome dessa modernidade "pacífica e segura" houvera o extermínio de inúmeras populações tradicionais, dentre as quais povos indígenas e etnias, com a simples justificativa de uma padronização de usos e costumes. 
A vida no seringal descrita por Maia, possuía uma dinâmica social própria, extemporânea às leis do Estado. No seringal quem determinava as leis era o seringalista, assim segundo Benjamin o uso da violência servia como compulsão para docilizar os comportamentos dos seringueiros (BENJAMIN, 1986, p.196).

No livro Banco de Canoa: cenas de rios e seringais da Amazônia (1997), o realismo das histórias sobre a sociedade em formação na Amazônia, demonstra como a degradação e aviltamentos cercaram as relações de entre patrões e empregados no seringal, descrevendo a barbárie envolvida no processo civilizatório da região. As descrições dos castigos dos seringalista sobre os seringueiros "rebeldes", ou os crimes sexuais cometidos contra as cunhãs pelos patrões, demonstram os requintes de crueldade, ao passo que demonstram a falta de ingerência das leis do Estado brasileiro em determinadas regiões, em pleno período republicano: "Estes seringueiros (seringalistas) levam a vida de fazendeiros ricos ou aristocratas rurais, cercados,- à moda de barões medievais,- por serviçais indígenas e suas famílias” (MAIA, 1997. p. 77).

Walter Benjamin (1986. p.196) reflete sobre a pobreza das experiências envolvidas no projeto civilizador. Se o processo civilizador foi pensado para tornar as pessoas melhores, os meios para se alcançar tal objetivo não são dos mais redentores, em favor do "atual", a humanidade empenhou um alto preço, ficando a mercê de inúmeras crises econômicas e guerras: “[...] a tenacidade é hoje um privilégio de um pequeno grupo de poderosos que, Deus sabe, não são mais humanos que a grande maioria; geralmente são mais bárbaros, mas não no bom sentido" (MAIA, 1997. p.133). Neste sentido, percebe-se que esse processo foi adquirido sob um alto preço, marcado pela violência e pela barbárie em nome da modernidade.

Álvaro Maia então revela essa relação sendo marcada por um civilizador (o seringalista), trapaceiro, desumano e criminoso enquanto que seringueiro é o trapaceado, diante dos "contratos" entre esses dois agentes. No entanto, o seringalista não deverá ser responsabilizado por tais condutas, pois faz em nome da civilização, ou seja, trata-se da vitória da civilização como podemos observar na descrição sobre a personagem do Coronel Terêncio do livro Banco de Canoa:

[...] Comeu as mulheres dos seringueiros, tirou os três vinténs das cunhãs de treze anos, furtou no peso das mercadorias, negou remédio na hora-da-morte, matou e incendiou. [...] Inutilizado para as cunhãs, 
mandava pegá-las pelo Nicó, pretalhão da cozinha, e ria, mas parecendo um corujão (MAIA, 1997. p.133)

A sociedade amazônica conformou-se e deixou-se ser vencida pela moderna sociedade ocidental, representada aqui pela figura do seringalista, transformando sua própria relação com a natureza, que outrora se mantinha por uma sociabilidade ligada ao valor de uso, agora incorporada a lógica do capitalista que tem suas relações exclusivamente ligadas aos valores de troca, sendo estas as transformadoras de todo o processo de sociabilidade na região. Diante deste cenário, a representação da sociedade moderna feita pela figura do seringalista na obra alvareana já traz consigo um processo de mudança na representação sobre acontecimentos e práticas sociais, que para os grupos tradicionais passavam por outro tipo de significação, essa modernidade trata todas essas práticas (crenças, hábitos, padrões morais) como antigas e portanto, devem ser vencidas e/ou substituídas.

\section{O OLHAR ALVAREANO SOBRE A POLÍTICA INTERIORANA}

As críticas políticas, e em especial a política no interior do Amazonas, estão fortemente retratadas na obra alvareana após a década de 1940. Lima (2009. p.100) afirma que as relações de poder surgem no Beiradão (1999), e em outros livros de Álvaro Maia através das descrições de situações cotidianas entre os pobres, os figurões poderosos e o religiosos. O Brasil sofria com um processo de regionalização política que era acentuada pelas práticas corruptas de um determinado grupo que dominava as esferas do poder e apenas reproduzia políticas que privilegiavam os interesses próprios em detrimento da coletividade. Neste sentido, Maia faz um retrato sobre a política brasileira através do recorte na região amazônica, criticando as manobras políticas, os apadrinhamentos políticos e as disputas pelo poder, conforme afirma no seguinte trecho: "Há nas histórias abordando as relações políticas interioranas a predominância da noção de que a não aderência a um grupo político pode resultar em perseguições e enxovalhamento" (MAIA,1999, p.93).

É interessante observar o posicionamento crítico em seu pensamento durante as décadas de 1950 e 1960, uma vez que já não contava com a harmonização política obtida durante a Interventoria no Estado Novo. Com um sistema extrativista enfraquecido e o aumento do êxodo rural, Maia tinha que manter uma posição de 
imunidade diante do processo de desagregação da borracha, onde conforme Santos (1996, p.188) já vinha sofrendo duras críticas devido a desorganização em relação aos programas de produção da borracha durante a década de 1940.

Partindo da lógica weberiana de que o Estado é uma fonte de poder e que o político invariavelmente busca o poder, o que estava em jogo era o manejo da literatura como mais um recurso para adquirir esse poder, seja para cumprir sua missão de intelectual com uma proposta para a formação da identidade nacional, seja para gozar de certo prestígio então enfraquecido como o fim do Estado Novo. Esse processo faz parte da própria condução da luta política.

Note o posicionamento ambíguo de Maia em torno da condição do seringalista em relação a política no interior, abordada neste livro assim como em outros de seus livros, a crítica ao governo é tratada no Beiradão, na medida em que exime da culpa o patrão seringalista, das condições de abandono e falta de assistência social no qual a população pobre do interior do Amazonas viveu ao longo da primeira década do século XX.

Segundo Skinner (1969. p.3) para a compreensão de qualquer afirmação de um autor, é necessário entender a motivação que o levou a fazer, ou seja, qual a pergunta que a afirmação supostamente pretende responder. Neste sentido, a abordagem dada por Maia onde a culpa do descaso com relação às camadas mais baixas da população amazonense, em nada tinha a ver com as relações entre patrões e empregados durante a extração da borracha, mas estava relacionada ao descaso com que o governo central tratou o homem do interior e suas particularidades. Assim quando constrói a personagem do velho Gusmão, no livro Beiradão (1999) como um seringalista que se tornou uma espécie de "curandeiro" estava tentando suprir uma necessidade básica da população que vivia em completo descaso.

O ponto central da intencionalidade política presente na obra literária de Álvaro Maia é mostrar as condições que o tornaram um líder intelectual e político responsável pela construção do projeto de modernização conservadora na região, todavia não se deve achar que a sua produção literária servia apenas para essa finalidade. Como um líder carismático sabia que não seria apenas o manejo das condicionantes simbólicas o suficiente para a sua permanência no campo político, é neste sentido, em que a literatura surge como um condicionante simbólico. Weber (2001. p. 70) afirma que o poder da crença em um líder carismático não se configura 
como a única forma de garantir a disputa nesse jogo político. Antes reside na natureza dos meios que o político dispõe para exercer sua autoridade, isto é, ele necessita de meios materiais e conhecimento administrativo para exercer seu domínio.

Portanto, a passagem de Álvaro Maia pela política tratou-se de uma realização prática de seu projeto de modelagem moral da prática do poder, e ao mesmo tempo da construção de uma rede de relações sociais e tomadas de decisões que possibilitaram a sua permanência, na medida em que se tornou porta-voz de um grupo que também defendia proteção dos interesses de determinado segmento econômico. Essa ideia da moralização da política surge no tom crítico em relação as práticas políticas interioranas.

No livro Banco de Canoa (1997) as descrições sobre a política local, revelam uma nítida preocupação do autor em descrever os "tipos de políticos" que enriqueciam em detrimento do "pobre" trabalhador do seringal. Como um representante da elite tradicional, Maia procurava tipificar esses tipos sem vinculá-los ao grupo político do qual ele fazia parte. Apesar de que nas décadas de 1950 e 1960, sua legitimação política sofrera com os novos grupos vinculados ao populismo, procurava na formação da identidade cabocla uma estratégia de recuperação de sua posição política, na medida em que as mudanças econômicas e políticas pelas quais o estado passava, tornavam seu discurso antiquado e retrogrado. No entanto, a estratégia de permanecer como um defensor da política tradicional em muito pode ser revelada através da construção de suas personagens nas últimas décadas de sua vida. Neste período o representante de uma elite decadente gomífera, oriundo de uma geração preocupada em delimitar uma identidade legitimamente cabocla, procurava conservar a estrutura política tradicional.

No capítulo sobre as farsas politiqueiras do livro Banco de Canoa (1997), Maia inicia com uma citação de Affonso Henriques sobre o cenário político brasileiro após a década de 1930, no qual critica o sistema eleitoral brasileiro implementado após este período; em sua crítica, a grande massa da população ainda se seduzia por pequenos “presentes". Em uma nota explicativa antes da apresentação das crônicas o autor afirma que os pleitos no interior eram constituídos por inúmeras irregularidades e uso de violência. $\mathrm{O}$ voto do cabresto era uma prática comum no interior de diversos estados do Brasil.

Através da personagem do Coronel Pedro Pilão deste livro, Maia descreve o modo como as eleições no interior do estado eram feitas, sendo marcadas por 
irregularidades, punições severas aplicadas aos oposicionistas. ${ }^{1}$ Neste sentido, o tom crítico, revela também um deslocamento entre a realidade política local e a política central, pois os regionalismos políticos demonstravam uma dissonância e falta de integração no projeto republicano brasileiro: "Nada se fazia sem ouvir Pedro Pilão. Resolvia a seu bel-prazer, alegando instruções secretas de chefões. Rasgava inquéritos, prendia e soltava" (MAIA, 1997, p.180).

Segundo Mario Ypiranga Monteiro (1976. p.50) a literatura amazonense nas primeiras décadas da República Velha tratava o seringueiro enriquecido com um tom de deboche, atribuindo-lhe certa estupidez, pois não havia um preparo para o convívio junto a sociedade burguesa. Álvaro Maia descontrói esse estereótipo ressaltando a importância deste tipo de seringalista para um projeto de construção da identidade nacional, na medida que os coloca na posição de desbravadores, tanto quanto o seringueiro. Trata-se de uma desmistificação do anti-herói, que surge como um movimento de rebeldia contra as construções dos tradicionais estereótipos de alguns literatos que escreviam sobre esses temas.

Neste sentido, o papel de narrador dessas histórias, confere-lhe uma posição segura dentro do processo de construção da opinião pública, pois sua missão como intelectual é construir a consciência sobre o atraso nacional, não mais pautado na ideia de um "país novo" e sim ligado a um subdesenvolvimento que precisa ser combatido a partir de uma nova tomada de consciência por parte da sociedade brasileira.

Note a intencionalidade de Álvaro Maia em descrever as eleições no interior do estado, quando o candidato da oposição vence, são rasgados todos os votos e refeitos impossibilitando a tentativa de mudança da ordem vigente, onde até o escrivão é punido severamente. Tais medidas servem para organizar politicamente as sociedades interioranas e manter a ordem e a disciplina: "Com gente assim, o Brasil não vai pra diante e cai na indisciplina" (MAIA, 1997, p. 143). O autor usa de ironia para afirmar que em determinadas regiões do Brasil o projeto republicano falhou e a política ainda é regida pelo coronelismo. Neste sentido, o discurso de defesa da ordem e da disciplina surge como uma estratégia dentro do jogo político para a permanência dos grupos oligárquicos que ainda resistiam no poder, através de feudos políticos.

1 Álvaro Maia faz referência ao caso das professoras opositoras que seriam esculhambadas pelos guris, que receberam ordens de depredar a sala de aula, ou o turco do regatão que pagaria alta multa). 
A sociedade moderna capitalista reproblematiza o papel da literatura, que acaba assumindo um caráter de ambiguidade, pois esta pode ser a expressão de valores favoráveis a manutenção da alienação, ou usada para oferecer as condições para a emergência da transgressão e da resistência. Todavia, Chaia (2007. p. 20) afirma que o papel do criador é fundamental para compreender o próprio sentido da arte e sua finalidade social, por serem linhas muito tênues, o engajamento social pode incidir de inúmeras maneiras no processo da criação. Ou seja, a posição política assumida pelo artista não subjuga sua obra que ainda mantem suas qualidades estéticas, pois este possui a capacidade de transmitir de forma poética e sensível a sua arguta percepção da realidade. Portanto, Álvaro Maia ao produzir sua obra literária, buscava mostrar antes de mais nada, suas visões sobre a realidade do povo amazônico e o modo como o jogo político se conduz no sentido de garantir a permanência de determinados grupos no poder.

A postura literária de Maia sofreu duras críticas de outros escritores deste período devido ao forte cunho ideológico da sua obra literária convertida a um engajamento político. Ao abordar a problemática do seringueiro, envereda pelo engajamento social na medida em que assume a temática na qual trata o drama vivido pelo seringueiro a partir de uma espécie de ajuste de conta entre freguês e patrão. Monteiro compara a abordagem de Álvaro Maia com a abordagem trabalhada por Francisco Galvão, no livro Terra de Ninguém, publicado em 1934, que também apresenta um forte cunho ideológico. No entanto, Francisco Galvão consegue ser mais corajoso em sua empreitada de descrever as relações de poder dentro do seringal, denunciando como o projeto burguês civilizatório fracassou na Amazônia na medida em que o homem não consegue romper com o processo de atomização da modernidade.

No plano político a obra de Francisco Galvão enfoca a crítica à política local amazonense. Todavia, é interessante salientar a ironia feita ao posicionamento político de Maia, que notadamente manejava sua obra no sentido de que seu engajamento político saísse da esfera do simbólico literário e entrasse na esfera prática. Assim, quando Francisco Galvão elabora a personagem de Alberto Maia, essa personagem é uma caricatura de Álvaro Maia que reflete a convergência ideológica no plano literário de ambos, ao criticar as facções políticas tradicionais, mas ao mesmo tempo revela as divergências em termos de posicionamento político, pois quando aborda essa 
personagem (um referência as iniciais de Álvaro Maia), o retrata como um poeta imbecil de melenas enormes e ideias curtas (SIQUEIRA, 2015, p.4).

Além da crise econômica o Amazonas, Álvaro Maia apresentou uma continuidade entre o regime autoritário de Vargas e o período de redemocratização. Representava essa continuidade, pois segundo Santos (1996. p.240) não houve o desmantelamento da estrutura política do Estado Novo e, também, não houveram rupturas ou mudanças radicais nos grupos políticos dominantes. Os governos democráticos de Álvaro Maia, Plínio Coelho e Gilberto Mestrinho não revelam um processo de cisão em que se alinhariam com as mudanças nacionais pretendidas através dos governos defensores do nacional-desenvolvimentismo.

Todavia, em seu pensamento reflete uma tentativa de alinhar os discursos tradicionais que o tornaram um místico líder intelectual e político com as novas demandas sociais, buscando dessa maneira conciliar suas ideias tradicionais com as mudanças em curso na sociedade brasileira que exigiam novas posturas menos discursivas dos políticos profissionais, bem como novas abordagens temáticas na produção literária, apesar de que ficou conhecido por um ufanismo exacerbado, sendo acusado inúmeras vezes de não produzir personagens com densidade literária, beirando apenas a uma compilação histórico documental, fortemente ligadas a ideais políticos.

Partindo de uma ideia de ambiguidade, Álvaro Maia não propõe de fato um uso de elementos literários que proponham uma estética de vanguarda, como propunha os escritores pertencentes ao Clube da Madrugada $^{2}$, sua aquisição de elementos modernos refere-se ao uso do rádio para a comunicação, do avião para facilitar o escoamento da produção. Isso faz com que sua obra se aproxime de um novo grupo social que está em ascensão nas décadas de 1940 a 1960 - a classe média urbana, que passa a ser a nova consumidora de sua obra literária. Neste sentido, a própria obra literária concorre com novos produtos culturais na Amazônia restando ao literato adaptar-se a esses novos recursos, tais como o rádio, cinema, etc.

A personagem do piloto de avião que salva a vida de uma menina no livro Gente dos Seringais (1956) revela uma preocupação do autor em estar integrado à modernidade na qual a sociedade amazonense estava se inserindo. Ao mesmo tempo o

2 Clube da madrugada era um movimento artístico e literário ligado a Geração de 45, esse grupo de artista além enfatizar suas preocupações estéticas faziam profundas críticas sociais ao governo vigente. 
caráter valoroso desta personagem, sacrificando o próprio posto para salvar a vida de uma pequena brasileira, em muito revela uma retomada da retórica de Maia em se colocar na condição de um intelectual que se "sacrificou" em favor do bem estar amazonense ao assumir a posição de engajar-se na política. $\mathrm{O}$ emaranhado de eventos narrados ligados a figura do avião busca através da construção de várias histórias relatar a condição da população do interior do Amazonas, vítima do descaso e do esquecimento em pleno século XX, ou seja, em uma espécie de autodefesa, ele encarnava a condição de um intelectual e político que assumia o risco de sacrificar-se no sentido de criar uma identidade cultural amazônica e ao mesmo tempo contribuir para o seu desenvolvimento. No livro Nas Barras do Pretório, publicado em 1958, Álvaro Maia afirma que Vargas, já morto, se sacrificou em favor da nação, esse sacrifício foi feito em favor do próximo, não o deixando imune às críticas vindouras, sendo este então o legado deixado por Vargas ao seus descendentes, do qual ele próprio era um destes. Inspirado no legado recebido por Vargas, tentava demonstrar uma certa despreocupação com possíveis críticas.

$\mathrm{Na}$ medida em que usa esses elementos reais e/ou sociais esses deixam de serem usados como elementos externos da obra e se tornam parte da própria estrutura (CANDIDO, 2006. p. 70). Ou seja, o aspecto simbólico do uso do avião na tradicional atividade extrativa da borracha, em muito revelam críticas sociais ao próprio modelo extrativo, no qual a máquina assume um caráter salvador em uma realidade social esquecida do resto do país.

Do mesmo modo, aborda a questão da abertura de estradas para a integração da região amazônica. Quando descreve o difícil processo de abertura das rodovias pelas próprias condicionantes geográficas, busca adaptar determinados termos ao processo de desenvolvimento do capitalismo para a realidade tradicional da economia amazônica, como no caso da indústria extrativa, sediada no seringal, o autor critica a criação de novas rodovias como um empreendimento inadequado para região amazônica, acreditando serem os rios e os aeroportos as alternativas mais viáveis para o desenvolvimento econômico da Amazônia. Neste sentido, critica em seu livro Gente dos Seringais que muitos projetos nacionais para a região foram criados em dissonância com a realidade local: “[...] por muitos anos, os rios e os aeródromos serão as únicas válvulas do comércio e do movimento no Amazonas" (MAIA, 1956. p.375). 
Portanto, é possível romancear e encontrar um tom poético na centralidade da temática da borracha na obra de Álvaro Maia, partindo de uma ideia desenvolvida por Gondim (1994. p.103), ao encararmos a borracha como o denominador comum, atuando como herói e vilão, o assassino e a vítima, o explorador e o explorado, ou seja, como o verdadeiro e principal personagem na obra alvareana, ligando assim suas crônicas, poesia, contos e romances, ao seu ideário de ação política. Onde o político a via como uma estratégia de desenvolvimento social e econômico para a região e o escritor via como um tema que explicava a Amazônia, sua verdadeira ocupação e processo civilizatório. Através da borracha era possível integrar a região à moderna civilização ocidental e encerrar de uma vez por todas a pechas preconceituosas e deterministas de que a sociedade que aqui se estabilizou, não evoluiu gerando um povo apático e indolente. Maia ao tratar em sua obra a temática da borracha, demonstra a superioridade do povo amazônida, demonstrando além de plena capacidade econômica de desenvolvimento, a ascensão de uma intelligentsia "filha da terra", capaz de identificar a cultura desta gente e sua contribuição para o desenvolvimento da sociedade.

A preocupação dos intelectuais dos primeiros anos da República Velha até 1945 era de forjar a nação no sentido de identificar os sinais de caráter e temperamento da população, após este período houve a defesa de que era ainda necessário um Estado forte para forjá-la, porém, segundo Pécaut (1990. p.50) não havia mais dúvida de que existia uma nação brasileira nas gerações posteriores até o Golpe Militar. A sociedade brasileira já possuía identidade própria, com interesses econômicos próprios, vontade política e cultura; uma vez que havia criado um projeto de organização social e política de forma consolidada, não poderiam mais falar de uma formação nacional, o projeto Estado-Nação teve tempo suficiente para ser experimentado internamente e externamente. O sentimento de identidade nacional foi substituído pelo de confronto, onde o povo começa a se identificar como povo. Não havia mais a necessidade da missão dos intelectuais de décadas anteriores de serem os representantes do projeto de nação, a fusão entre povo e nação selou-se definitivamente com os episódios da criação da Petrobrás e o suicídio de Vargas em 1954.

Na caracterização de Lukács (1966. p.55) a consciência histórica do romancista fala mais do que apenas uma representação do passado. A partir dessa consciência é que o escritor estará habilitado a conhecer adequadamente o seu povo para extrair desse 
Disponível em: www.revistafenix.pro.br

conhecimento a "verdade histórica". Essa, transfiguração, garante a totalidade ideal do romance tal como é encontrada exemplarmente nos grandes mestres do século XIX. Neste sentido, Maia só conseguira construir uma literatura "realista" da Amazônia a partir da tomada de consciência sobre as forças históricas que estavam em disputa, assim o autor conseguiu construir personagens extraídos das disputas e interações desse cotidiano, sendo este um sujeito médio que experimenta forte vínculo com seu grupo social.

De que maneira os intelectuais marginais manejavam o nacionalismo estatal? e/ou posteriormente o nacionalismo populista seja denunciando ou amenizando as contradições da sociedade capitalista. Para este propósito, a literatura foi tomada para revelar a degradação das classes mais baixas da sociedade. Enquanto algumas parcelas da sociedade, entre as quais podemos citar a classe média, modernizavam-se e atingiam os patamares de cidadania e civilidade, havia porém um grupo que estava de forma ambígua encontrando-se materialmente à margem deste processo moderno civilizador, todavia experimentava simbolicamente uma inserção cultural e política. Álvaro Maia busca desvelar no homem interiorano da Amazônia essa relação ambígua com a modernidade.

Diferente de outros escritores da borracha, os detalhes sobre o labor na extração gomífera não era o principal interesse de Maia e sim as relações sociais e de poder que se desenrolam a partir desta cultura extrativista. Pois são através destas relações que o autor procura encontrar o indício da crise da civilização burguesa, e em esfera local as atitudes e ideias sociais brasileiras formaram uma classe média urbana totalmente inserida neste processo. O homem do campo, todavia, aparece de modo deslocado nesse processo.

A “anomalia social” criada pelas condições sociais e políticas no interior do ciclo da borracha na Amazônia, privava ao seringueiro oportunidades de respeitabilidade do trabalho assalariado que obrigava a buscar seu sustento em relações de proteção e clientelismo. Neste sentido, como esse caboclo interiorano poderia ser moderno e civilizado dentro das condições geradas pela economia gomífera? A resposta se dava pela construção de uma ordem social diferente no interior, ligada a cultura popular, as relações políticas e econômicas locais, que imprimiam um modelo reduzido da sociedade brasileira, no entanto, que revelava o verdadeiro retrato do Brasil: a Caboclitude. 
Os livros de Álvaro Maia Defumadores e Porongas (1966), Gente dos Seringais (1956), Banco de Canoa (1997), fazem uma compilação de crônicas, ou narrativa de pequenas estórias, nas palavras do autor sobre a vida no seringal. Essas crônicas possuem temáticas e personagens que se repetem como a condição pioneira dos trabalhadores da borracha, o papel singular dos padres nos seringais amazônicos cujas condições sociais, ecológicas e econômicas transformavam o processo de catequização, a relação do homem com os mitos e lendas amazônicas e as relações políticas e de poder no interior do estado, entre outros temas mais gerais tais como os impactos sociais, econômicos e políticos da aviação, da abertura de novas estradas e outros impactos modernos na região. Deixam desvelar a crítica do autor em compreender como a modernidade e suas transformações impactaram a região que se encontra na periferia do sistema capitalista, que durante a primeira metade do século XX se encontrava em vertiginosa expansão. Todavia, no Amazonas, o homem interiorano, o seringueiro, o indígena, o padre, entre outros, sofreram profundos impactos.

Neste sentido, ao qualificar esses atores sociais Álvaro Maia apresenta um retrato das transformações sociais nas quais o Brasil passava, a partir do olhar das "bordas" de um processo global. Ou seja, o autor retratava uma realidade vista pelos olhos e pelas vozes silenciadas e/ou alienadas do processo de modernização. Maia foi considerado pela análise literária específica atual um autor que construía personagens planos e produzia uma construção literária fortemente carregada de maniqueísmos, ficando sua obra literária presa mais ao cunho documental do que ao ficcionista. Sua obra, apesar de manter um laureamento junto aos seus pares da época, estava ligada também a uma consagração conquistada na esfera política, tangenciando-se assim de construções literárias comuns aos dos grandes cânones, por este motivo o autor foi estereotipado como uma figura a ser "engolida" mais pela sua condição social política do que pelo valor de sua arte. ${ }^{3}$

\section{CONCLUSÃO}

A partir da revolução na década de 1930 e posteriormente o estabelecimento do Estado Novo, os intelectuais brasileiros já não buscam em seus estudos identificar a

3 Nos últimos anos as análises literárias especializadas, vem colocando Álvaro Maia na condição de um escritor marginal, pela qualidade de suas obras e a forte ingerência política. 
identidade nacional. Uma vez superados tais questionamentos, buscou-se compreender de que maneira as instituições liberais falharam. Por este motivo o Estado Novo é visto como um recorte com o passado, um reencontro consigo mesmo, um Brasil Novo. Os intelectuais brasileiros, tais como o próprio Álvaro Maia foram cooptados pelo Estado para tornarem-se seus ideólogos. Assim, ao invés de tentar explicar o atraso nacional, buscou-se criar elementos que reforçassem a ideia de que a própria sociedade seria apta a criar esse novo Brasil. E, para esse projeto era necessário um Estado forte, com um líder que seria capaz de guiar a nação para essa nova fase da história brasileira.

É interessante salientar a ambiguidade presente nas ideias de Álvaro Maia, de reforçador das ideias de modernização das instituições liberais, crítico do projeto liberal e defensor do autoritarismo. Os pensadores do liberalismo demonstravam certa tolerância às ideias de regimes autoritários, essas ideias em última instância, levavam os valores de ordem e respeito às hierarquias inerentes ao liberalismo.

A partir do momento em que fica claro que a produção literária de Álvaro Maia não foi meticulosamente construída no sentido de garantir sua inserção no campo político, podemos compreender que, como um dos representantes do movimento do regionalismo, via na literatura nativista uma forma de construir uma identidade verdadeiramente amazônica. Contudo, como representante do grupo conhecido como Caboclitude surge também como uma estratégia da elite conservadora decadente em permanecer no poder. De origem abastada, procurou manter um discurso conciliatório com os grupos economicamente dominantes da região. As décadas de 1950 e 1960, no entanto, revelam um posicionamento mais crítico de seu pensamento. No entanto, não se deve esquecer que já não contava com a harmonização política obtida durante a Interventoria no Estado Novo. Durante este período sua atuação política passou por uma profunda instabilidade.

Contudo, a produção literária de Álvaro Maia buscou compreender como a modernidade e suas transformações impactaram a região amazônica criando dilemas, sendo que o homem interiorano, o seringueiro, o indígena, o padre, entre outros personagens criados pelo autor, refletem o nível destes impactos.

\section{REFERÊNCIAS BIBLIOGRÁFICAS}


BASTOS, É. R. \& PINTO, R. Os Intelectuais e a questão regional. In: BASTOS, É. R. \& PINTO, R. (Org.).Vozes da Amazônia: Investigação sobre o pensamento social brasileiro. Manaus: Valer/ EDUA, 2014. 09-25 p.

BENJAMIN, Walter. Documentos de cultura, documentos de barbárie: escritos escolhidos. Seleção e apresentação Willi Bolle; tradução Celeste H. M. Ribeiro de Sousa (et al.). São Paulo: Cultrix/Edusp, 1986. 201 p.

BOURDIEU, Pierre. As regras da arte. São Paulo: Companhia das Letras. 1996. 431 p. CANDIDO, Antonio. Literatura e Sociedade. Rio de Janeiro, Ouro Azul, 2006. 199 p

CHAIA, Miguel. Arte e política: situações. In: . Arte e Política. Rio de Janeiro: Azougue, 2007. p. 13-39.

ELIAS, Norbert. O processo civilizador. Traduzido por Ruy Jungmann. vol 1.Rio de Janeiro: Jorge Zahar, 1994. 279 p.

GOLDMANN, Lucien. Origem da dialética: A comunidade humana e o universo em Kant. Tradução de Haroldo Santiago. Rio de Janeiro: Paz e Terra, 1967. 254 p.

GONDIM, Neide. A invenção da Amazônia. São Paulo: Editora Marco Zero, 1994. $278 \mathrm{p}$.

LIMA, Luciene Gomes. Ficções do Ciclo da borracha. Ed. EDUA; Manaus, 2009. 241 $p$.

LUKÁCS, Georg- Estética: la Peculiaridad de lo Estético. Vol. 1: Questiones Preliminares y de Principio. Traduzido por Manuel Sacristán. Barcelona: Grijalbo 1966. $434 \mathrm{p}$.

MAIA, Álvaro. Na Vanguarda da Retaguarda. Manaus: DEIP, 1943. 354 p. Álvaro. Gente dos Seringais. Rio de Janeiro: Bosol, 1956. 375 p Nas Barras do Pretório. Manaus: 1958. 200 p. Álvaro. Defumadores e Porongas. Manaus: Imprensa Oficial, 1966. 266 p. Álvaro. Banco de Canoa: Cenas de rios e seringais do Amazonas. $2^{\circ}$ Edição.

Manaus: UA, 1997. Álvaro. Beiradão. Manaus. $2^{\circ}$ ed. Manaus: Valer/UA, 1999. 270 p.

MONTEIRO, Mario Ypiranga. Fatos da literatura amazonense. Manaus: Universidade do Amazonas, 1976.

PAIVA, Marco Aurélio Coelho de. Identidade regional e folclore amazônico na obra de Mário Ypiranga Monteiro. Manaus: Valer, 2002.

PÉCAUT, Daniel. Intelectuais e a política no Brasil: entre o povo e a nação. Tradução de Maria Júlia Goldwasser. São Paulo: Ática. 1990. 335 p.

SANTOS, Eloína Monteiro dos. Uma liderança política cabocla: Álvaro Maia. Tese (Doutorado em História Social) - Faculdade de Filosofia, Letras e Ciências Humanas). Universidade de São Paulo. São Paulo. 1996.

SIQUEIRA, Marklize Santos. O romance social de Francisco Galvão: Expressões de uma representação da cultura na Amazônia. In: Revista Elaborar. Vol. 02, ano 3, n. 1, 2015. Disponível em: www.periodicos.ufam.edu.br.view. Acessado em: 08 de ago. 2019.

SKINNER, Q. "Meaning and Understanding in the History of Ideas". History and Theory, vol. 8, n. 3, 1969. 3-53 p.

WEBER, Max. A política como vocação. Tradução de Jean Melville. Ciência e Política duas vocações. São Paulo: Martin Claret, 2001. 
Disponível em: www.revistafenix.pro.br 